\title{
Correspondence
}

\section{Central antiemetic effect of atropine: our personal experience}

\section{To the Editor:}

We want to report our original, effective and non-expensive method of preventing emesis during segmentary spinal analgesia. According to our method, atropine sulphate is administered together with opioids in the epidural or subdural space. Until now we have treated 30 patients ( 21 female and 10 male) suffering from cancer pain, 15 by the epidural and 15 by the subarachnoid route after approval from the Ethics Committee and with the patient's informed consent. All patients were previously treated with the usual oral antiemetics. When the emesis was intractable we added $20 \mu \mathrm{g}$ atropine to $3 \mathrm{mg}$ morphine in the case of epidural and $15 \mu \mathrm{g}$ atropine to a single bolus of $\leq 0.6 \mathrm{mg}$ morphine for subarachnoid injection. Total daily doses of atropine can range, according to the number of administrations, from 60 to $80 \mu \mathrm{g}$ for the epidural and from 45 to $60 \mu \mathrm{g}$ for the subarachnoid route. We have always obtained complete suppression of nausea and vomiting even if we doubled the daily opioid dose without any side effects.

Our idea arose from the observation that the chemical formula of atropine (MW 289) is similar to that of cocaine (MW 303) and meperidine (MW 247) and we hypothesised that atropine could occupy opioid receptors preventing the emetic effect (Figure). ${ }^{1}$ Another explanation is possible: it is likely that atropine can act as a 5HT3 receptors antagonist, like other new antiemetics: MDL72222, ICS 205.930 and granisetron, that derivate from tropine esterified respectively with benzoic and indolic acid, and whose molecule is closely linked with cocaine, that was one of the first reference molecules for the synthesis of new 5HT3 antagonists. ${ }^{2}$

\section{F. Ramaioli MD}

D. De Amici MD*

Department of Anaesthesia and Intensive Care $2^{\circ}$

*Department of Clinical Epidemiology and Biometry

IRCCS Policlinico San Matteo

Piazzale Golgi, 2

27100 Pavia - Italy

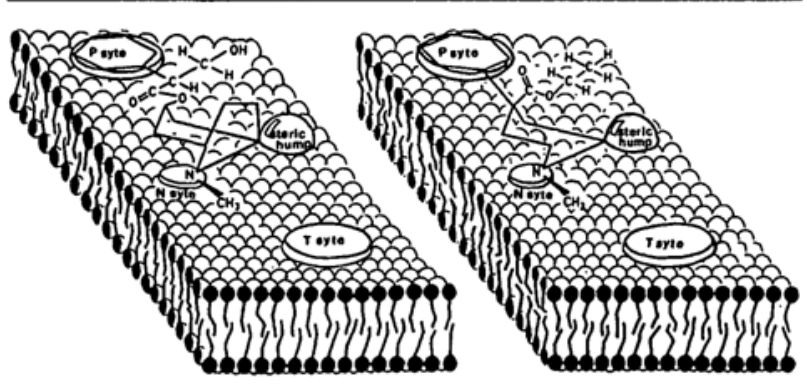

FIGURE Plastic model of the opiate receptor simplified according to Thorpe (1984).
REFERENCES

1 Thorpe $D H$. Opiate structure and activity - a guide to understanding the receptor. Anesth Analg 1984; 63: 143-51.

2 Fozard JR, Mobarok Ali AT, Newgrosh G. Blockade of serotonin receptors on autonomic neurones by (-)-cocaine and some related compounds. Eur J Pharmacol 1979; 59: 195-210.

\section{Central anticholinergic syndrome complicating management of a difficult airway}

To the Editor:

An 83-yr-old woman required urgent thyroidectomy, as her thyroid tumour was compromising her airway. Fibreoptic intubation (FOI) was planned and scopolamine, $0.4 \mathrm{mg} i v$, was administered preoperatively. Ten minutes later the larynx could not be visualized fibreoptically in the sedated patient and within five minutes she became apnoeic. Emergency tracheostomy followed unsuccessful direct laryngoscopy. Three hours after surgery, the patient, although rousable, remained agitated and uncooperative. Temperature was $37.9^{\circ} \mathrm{C}$ and the pupils were dilated. Neurological examination was normal. Physostigmine, $1 \mathrm{mg} i v$ was administered and the patient immediately became calm and cooperative.

Airway management in the presence of airway obstruction remains an anaesthetic challenge ${ }^{1}$ and even awake FOI may prove difficult. ${ }^{2}$ The patient's airway "collapsed" after sedation with scopolamine; the iv route was chosen for rapid onset. ${ }^{3}$ Scopolamine-induced amnesia and sedation are accentuated in elderly patients where coma and respiratory depression with clinical doses have been described. ${ }^{5}$

Central Anticholinergic Syndrome (CACS) is a complication of antimuscarinic drugs and is implicated in many cases of postoperative agitation. ${ }^{4}$ Patients may exhibit motor incoordination, nausea and vomiting, hallucinations, shivering, fever, as well as dry mouth and skin, tachycardia and photophobia. ${ }^{5}$ Because of the multiplicity of factors, the diagnosis of CACS is often presumptive. Resolution of symptoms occurs within 2-20 min of physostigmine administration.

We conclude that management of difficult airways may be complicated by the side effects of scopolamine, manifesting as CACS with coma and respiratory depression.

Tiberiu Ezri MD

Peter Szmuk MD

Sergio Konichezky MD

David Abramson MB ChB FFA

Daniel Geva MD

Departments of Anesthesiology

Kaplan Hospital, Rehovot, Israel and UT-Houston, Medical School

Houston, Texas 


\section{REFERENCES}

1 Pullerits $J$, Holzman $R$. Anaesthesia for patients with mediastinal masses. Can J Anaesth 1989; 36: 681-9.

2 Ovassapian A. Fiberoptic tracheal intubation. In: Ovassapian A (Ed.). Fiberoptic Airway Endoscopy in Anesthesia and Critical Care. New York: Raven Press, 1990: 57-79.

3 Omoigui S. The Anesthesia Drugs Handbook, 2nd ed. St. Louis: Mosby-Year Book, Inc, 1995: 317-8.

4 Banoub $M$, Nugent $M$. Thoracic anesthesia. In: Rogers MC, Tinker JH, Covino BG, Longnecker DE (Eds.). Principles and Practice of Anesthesiology. St. Louis: Mosby - Year Book, Inc, 1993: 1836.

5 Brown J, Palmer T. Atropine, scopolamine and related belladonna alkaloids. In: Molinoff P, Ruddon R (Eds.). Goodman and Gilman's: The Pharmacological Basis of Therapeutics, 9th ed. New York: McGraw-Hill, 1996: 149-54.

\section{Ciguatera and the anesthesiologist}

\section{To the Editor:}

Recently, we anesthetized a man recovering from ciguatera. Al though ciguatera is the most frequently reported food-borne disease due to chemical toxicity in the United States, there are no reports regarding the anesthetic management of patients suffering from this condition. ${ }^{1}$

Ciguatera results from the consumption of coral reef-associated fish contaminated by ciguatoxins. The symptoms can occur 10 minutes after ingestion of contaminated fish and include weakness, myalgia, vomiting, paresthesias and paradoxical reversal of temperature perception. Severe cases may present coma and respiratory paralysis. Recovery may take years. $^{2}$

Ciguatoxins trigger persistent sodium channel opening in excitable membranes. This results action potentials oscillations which cause bursts of spontaneous discharges. Manifestations of central nervous system involvement is only seen in severe cases. ${ }^{3}$ For the acute intoxication, mannitol is the treatment of choice but there is no specific therapy for the chronic condition. ${ }^{4}$

Our patient had a cholecystectomy. Six months earlier he suffered a severe ciguatera intoxication. He still complains of severe muscle pains and weakness.

The patient was anesthetized with midazolam, propofol, fentanyl, desflurane and rocuronium. The neuromuscular block was reversed with neostigmine and glycopyrrolate. We avoided succynylcholine because of the possibility of exacerbating the myalgias. Epidural analgesia was also avoided as not to confuse further evaluation of the patient's lower limb weakness and pains. The procedure was uneventful and the patient recovered without complications.

However, the pathophysiology of ciguatera poisoning suggests multiple anesthetic implications. Considering that the incidence of ciguatera is rapidly increasing, it behooves anesthesiologists to be familiar with this entity.

Rafael A. Ortega MD

Navinderdeep Singh

Ricarda Peine
Department of Anesthesiology

Boston University School of Medicine

88 East Newton Street

Boston, MA02118

\section{REFERENCES}

1 Katz AR, Terrell-Perica S, Sasaki DM. Ciguatera on Kauai: investigation of factors associated with severity of illness. Am J trop Med Hyg 1993; 49: 448-54.

2 Habermehl GG, Krebs HC, Rasoanaivo P, Ramialiharisoa $A$. Severe ciguatera poisoning in Madagascar: a case report. Toxicon $1994 ; 32 ; 1539-42$.

3 Cameron J, Capra MF. The basis of the paradoxical disturbance of temperature perception in ciguatera poisoning. J Toxicol Clin Toxicol 1993; 31: 571-9.

4 Lewis RJ, Hoy AW, Sellin M. Ciguatera and mannitol: in vivo and in vitro assessment in mice. Toxicon 1993; 31: 1039-50.

\section{Chewing gum prior to anaesthesia - is not age restricted}

To the Editor:

Patients are advised to refrain from chewing gum before anaesthesia. This is based on the fear that it might increase acid gastric secretion, ${ }^{1,2}$ gastric volume, ${ }^{3}$ and endotracheal tube obstruction. ${ }^{4}$

An 81-yr-old woman (ASA II) was scheduled for general anaesthesia for exploratory laparotomy. In the preoperative interview, no abnormality was noted as to her speech. No loose teeth were seen or reported. She had a full mobility of her tongue and the tip of the uvula was clearly seen. The airway was assessed as a class 1 . The patient was taken to the operating room and monitors placed. Preoxygenation was commenced, but prior to the anaesthetic induction with thiopentone, the patient asked "Is it time for me to take my chewing gum out?" We suggested that it was, and a wad of gum $(2 \mathrm{~cm}$ in diameter) was removed. Needless to say much to our surprise, as neither the preoperative staff nor ourselves had noted anything strange about her speech, nor saw her chewing. A potentially fatal airway obstruction could have ensued. ${ }^{4}$

Renae Tays MD

John G. Brock-Utne MD PhD FFA (SA)

Anesthesia Department, H3580

Stanford University Medical Center

Stanford, CA $94305-5115$

\section{REFERENCES}

1 Moore MW, Meyer RA. Elective ambulatory surgery: must the patient be 'NPO'? JAMA 1990; 263: 733.

2 Mather C, Strunin L. Preoperative drinking and gastric contents. Br J Anaesth 1993; 70: 701-2.

3 Søreide E, Holst-Larsen $H$, Veel T, Steen PA. The effects of chewing gum on gastric content prior to induction of general anesthesia. Anesth Analg 1995; 80: 985-9.

4 Bevacqua $B K$, Cleary $W F$. An unusual case of endotracheal tube cuff dysfunction. J Clin Anesth 1993; 5: 237-9. 